OPEN ACCESS

Edited by:

Theodore Nicolaides,

New York University, United States

Reviewed by:

Jens Gempt,

Technische Universität

München, Germany

Robin Buerki,

University Hospitals Cleveland Medical

Center, United States

*Correspondence:

Muhammad Omar Chohan

mchohan@umc.edu

Specialty section:

This article was submitted to

Neuro-Oncology and Neurosurgical

Oncology,

a section of the journal

Frontiers in Neurology

Received: 17 October 2020

Accepted: 14 January 2021

Published: 05 February 2021

Citation:

Kazim SF, Martinez E, Hough TJ,

Spangler $B Q$, Bowers $C A$ and

Chohan MO (2021) The Survival Benefit of Postoperative Bacterial

Infections in Patients With

Glioblastoma Multiforme: Myth or Reality? Front. Neurol. 12:615593.

doi: 10.3389/fneur.2021.615593

\section{The Survival Benefit of Postoperative Bacterial Infections in Patients With Glioblastoma Multiforme: Myth or Reality?}

\author{
Syed Faraz Kazim ${ }^{1}$, Erick Martinez ${ }^{2}$, Tyler J. Hough ${ }^{3}$, Benjamin Q. Spangler ${ }^{3}$, \\ Christian A. Bowers ${ }^{1}$ and Muhammad Omar Chohan ${ }^{4 *}$
}

\begin{abstract}
${ }^{1}$ Department of Neurosurgery, University of New Mexico Hospital (UNMH), Albuquerque, NM, United States, ${ }^{2}$ School of Medicine, New York Medical College (NYMC), Valhalla, NY, United States, ${ }^{3}$ School of Medicine, University of New Mexico (UNM), Albuquerque, NM, United States, ${ }^{4}$ Department of Neurosurgery, University of Mississippi Medical Center (UMMC), Jackson, MS, United States
\end{abstract}

Glioblastoma multiforme (GBM), the most common malignant brain tumor, universally carries a poor prognosis. Despite aggressive multimodality treatment, the median survival is 18-20 months, depending on molecular subgroups. A long history of observations suggests antitumor effects of bacterial infections against malignant tumors. The present review summarizes and critically analyzes the clinical data providing evidence for or against the survival benefit of post-operative bacterial infections in GBM patients. Furthermore, we explore the probable underlying mechanism(s) from basic science studies on the topic. There are plausible explanations from immunobiology for the mechanism of the "favorable effect" of bacterial infections in GBM patients. However, available clinical literature does not provide a definitive association between postoperative bacterial infection and prolonged survival in GBM patients. The presently available, single-/multi-center and national database retrospective case-control studies on the topic provide conflicting results. A prospective randomized study on the subject is clearly not possible. Immunobiology literature supports development of genetically modified bacteria as part of multimodal regimen against GBM.

Keywords: glioblastoma multiforme, bacterial infections, survival benefit, mechanism(s), immune response

\section{INTRODUCTION}

Glioblastoma multiforme (GBM), the most common malignant brain tumor, universally carries a poor prognosis (1-3). The current standard treatment for newly diagnosed GBM include maximal surgical resection, followed by radiation therapy given concomitantly with temozolomide (TMZ) followed by adjuvant TMZ chemotherapy (4-6). Despite aggressive multimodality treatment, the median survival is $\sim 18-20$ months, depending on molecular subgroups $(2,7,8)$. Extent of resection, adjuvant chemo-radiation, young age, high Karnofsky Performance Score (KPS), and DNA repair enzyme $O^{6}$-methylguanine-DNA methyltransferase (MGMT) promoter hypermethylation are factors associated with improved survival (9-11). 
It has long been speculated that postoperative bacterial infection may prolong survival in cancer patients by stimulating immune response (12). William B. Coley, an orthopedic surgeon and pioneer of cancer immunotherapy, was the first to extensively study the role of bacterial inoculants in cancer progression during the late nineteenth and early twentieth centuries (13-15). In 1891, he injected streptococcal organisms into a patient with inoperable cancer, and was able to show significant tumor shrinkage (15). Over the next 40 years, as head of the Bone Tumor Service at Memorial Hospital in New York, Dr. Coley injected more than 1,000 cancer patients with bacteria or bacterial products, known as Coley's Toxins, and reported favorable results, especially in bone and soft-tissue sarcomas (15). Later on, during midtwentieth century, Nauts et al. showed that several bacterial organisms and their products could induce tumor regression in malignant tumors in humans (13). In late twentieth century, with the universal adoption of aseptic surgical technique, advent of antibacterial pharmacotherapy, and the emergence of adjuvant chemo-radiation, interest in natural, iatrogenic, or induced infection as a therapeutic approach for patients with cancer fell out of favor $(16,17)$.

While there is a long history of observations suggesting antitumor effects of natural bacterial infections against malignant tumors (18), conflicting clinical neurosurgical evidence exists regarding the effect of post-operative bacterial infections on survival in GBM patients which precludes any definitive conclusion(s) (19-21). The present review summarizes the clinical data on the role of post-operative bacterial infections on survival in GBM patients. Furthermore, we explore the probable underlying mechanism(s) from basic science studies on the topic. The mechanistic insights from basic science provide a rationale for bacterial pathogens-related antitumor effect.

\section{CLINICAL STUDIES ON THE POTENTIAL ROLE OF POSTOPERATIVE BACTERIAL INFECTION ON SURVIVAL IN GBM PATIENTS}

Post-operative bacterial infections following surgical resection of GBM offer a passive conduit to study the role of pathogeninduced immunologic responses in tumor progression. However, the role of postoperative infection on survival in patients with GBM has not been rigorously studied. Our literature search identified one national database retrospective case-control study, one multi-center, retrospective case-control study, three single-center, retrospective case-control studies, and few case reports/series on the topic (Table 1). A recent multi-center, retrospective case-control study reported a significantly shorter survival in GBM patients with infections after surgery for primary tumors (median survival 381 days/12.5 months) as compared to control group (median survival 547 days/18 months) (22). Majority of infections in the study by Salle and colleagues were deep wound infections (22). Another study by Bohman et al. (19) in 2009, did not find a statistically significant survival advantage in 17 patients with postoperative infection after GBM resection (median survival, 13.1 months), out of 383 patients included in their single-center retrospective study. However, a moderate, statistically insignificant survival advantage was seen in the infected group, however, when patients with infections in the first quarter and first half of their postoperative survival period were analyzed, this survival advantage disappeared (19). There was no significant survival difference in any subgroup assessed, including deep infections, bone flap infections, or infections caused by any specific organism (19).

In contrast, a single-center, retrospective study by De Bonis and colleagues reported a survival benefit of post-operative bacterial infections in GBM patients (20). This study evaluated 10 post-operative surgical site infections in 197 GBM patients (20). Kaplan-Meier analyses revealed a significant survival advantage in infected patients (median survival 30 vs. 15 months in controls, Breslow test, $p<0.01$ and log-rank test, $p=0.01)(20)$. The cumulative survival probabilities at 1,2 , and 3 years for patients with and without postoperative infection were 100 and 42\%, 67 and $22 \%$, and 37 and $10 \%$, respectively (20). All patients had infections during the first quarter of their overall survival period, with Staphylococcus aureus being the most common pathogen (6 cases, 60\%) (20). Five patients had intracranial abscess; 3 patients had both abscess and surgical wound infection; and 2 patients had surgical wound and bone flap infection requiring surgical revision (20). The analysis of survival by pathogen and site of infection did not show any significant differences, owing to small sample size (20).

In a recent population based study, Chen et al. (21) analyzed 3,784 patients with GBM from the linked Surveillance, Epidemiology, and End Results (SEER)-Medicare database. They found that 154 (4.2\%) patients had infection (defined as bacterial or non-bacterial meningitis, intracranial abscess, or postoperative infection by ICD-9 coding) within the first month of surgery (21). In patients with GBM who had an infection within 1 month of surgery, there was no significant difference in survival (median, 5 months) compared with patients with no infection (median, 6 months, $p=0.17$ ) (21). Given limitations of the SEER database, this study could not provide further details on the type of organism or severity of infection.

In a case series, Alexiou et al. reported a survival time of 42 months in a GBM patient with postoperative bacterial infection, with an institutional median survival of 15.5 months (23). Another GBM patient in the same series with postoperative bacterial infection had an overall survival time of 14 years (168 months) (23). In two separate case report/series, survival times of 120 and 60 months, respectively, have been reported with postoperative bacterial infections $(24,25)$.

Antitumor effects of bacterial infections have also been described in central nervous system (CNS) tumors other than GBM. For example, regression of a skull base liposarcoma was reported after surgical site infection with Corynebacterium hemolyticum and Staphylococcus epidermis (26). There are also clinical studies outside the neurosurgical literature which hint toward a probable association between infection and survival in tumors. Ruckdeschel et al. (27) in a retrospective study evaluated 18 patients with lung cancer complicated by postoperative empyema. The 5-year survival rate for the empyema group 
TABLE 1 | Literature review of effect of postoperative bacterial infections on survival in GBM patients.

\begin{tabular}{|c|c|c|c|c|c|c|}
\hline References & Type of study & $\begin{array}{l}\text { No. of patients } \\
\text { with GBM }\end{array}$ & Major infection type & $\begin{array}{l}\text { Major offending } \\
\text { organism }\end{array}$ & $\begin{array}{l}\text { Survival } \\
\text { (months) }\end{array}$ & Outcome \\
\hline Salle et al. (22) & $\begin{array}{l}\text { Retrospective } \\
\text { case-control }\end{array}$ & 64 & $\begin{array}{l}\text { Deep incisional wound } \\
\text { infection }=25 \\
\text { Organ wound infection }=39\end{array}$ & $\begin{array}{l}\text { S. aureus }=20 \\
\text { S. epidermidis }=14 \\
\text { P. acnes or } C . \text { acnes }=5 \\
\text { Corynebacterium }=3 \\
\text { E. cloacae }=3 \\
\text { S. } \text { capitis }=3\end{array}$ & $12.5^{\dagger}$ & $\begin{array}{l}\text { Significantly shorter } \\
\text { survival in GBM } \\
\text { patients with } \\
\text { postoperative } \\
\text { infections }\end{array}$ \\
\hline Chen et al. (21) & $\begin{array}{l}\text { Retrospective } \\
\text { case-control }\end{array}$ & 154 & Not reported & Not reported & $5^{\dagger}$ & $\begin{array}{l}\text { No significant survival } \\
\text { advantage }\end{array}$ \\
\hline De Bonis et al. (20) & $\begin{array}{l}\text { Retrospective } \\
\text { case-control }\end{array}$ & 10 & $\begin{array}{l}\text { Abscess }=8 \\
\text { Wound } / \text { bone }=5\end{array}$ & $\begin{array}{l}\text { S. aureus }=6 \\
\text { S. epidermidis }=2 \\
\text { Gram positive }=2\end{array}$ & $30^{\dagger}$ & $\begin{array}{l}\text { Significant survival } \\
\text { advantage }\end{array}$ \\
\hline Bohman et al. (19) & $\begin{array}{l}\text { Retrospective } \\
\text { case-control }\end{array}$ & 17 & $\begin{array}{l}\text { Wound }=8 \\
\text { Abscess }=6 \\
\text { Wound/bone }=4 \\
\text { Meningitis }=3\end{array}$ & $\begin{array}{l}\text { S. epidermidis }=6 \\
\text { P. acnes or C. acnes = } 6 \\
\text { S. aureus }=4\end{array}$ & $13^{\dagger}$ & $\begin{array}{l}\text { No significant survival } \\
\text { advantage }\end{array}$ \\
\hline Alexiou et al. (23) & Case series & 2 & Wound infection & $\begin{array}{l}\text { S. hemolyticus }=1 \\
\text { S. epidermidis }=1\end{array}$ & 42,168 & Survival advantage \\
\hline $\begin{array}{l}\text { Bowles and } \\
\text { Perkins (24) }\end{array}$ & Case series & 4 & Wound/bone infection & $\begin{array}{l}\text { S. aureus and E. aerogenes } \\
=2 \\
\text { E. aerogenes }=1\end{array}$ & $120^{\star}$ & Survival advantage \\
\hline $\begin{array}{l}\text { Walker and } \\
\text { Pamphlett (25) }\end{array}$ & Case report & 1 & $\begin{array}{l}\text { Extra/subdural fluid } \\
\text { collection, } \\
\text { wound infection }\end{array}$ & S. epidermidis & 60 & Survival advantage \\
\hline
\end{tabular}

\footnotetext{
${ }^{\dagger}$ Median time.

*The study followed up cases up to 10 years (120 months).

C. acnes, Cutibacterium acnes; E. aerogenes, Enterbacter aerogenes; E. cloacae, Enterobacter cloacae; P. acnes, Propionibacterium acnes; S. aureus, Staphylococcus aureus; S. capitis, Staphylococcus capitis; S. epidermidis, Staphylococcus epidermidis; S. hemolyticus, Staphylococcus hemolyticus.
}

was $50 \%$ as compared to $18 \%$ for the control group consisting of 34 patients (27). In another study, Jeys and colleagues evaluated the effect of postoperative infection in patients treated for osteosarcoma, using endoprosthetic replacement and neoadjuvant chemotherapy (28). The study reported that patients with osteosarcomas who had postoperative infection had a survival rate of $84.5 \%$ at 10 years $(n=41)$ compared to $62.3 \%$ in the noninfected group $(n=371 ; p=0.017)$ (28). It was found that infection was an independent prognostic factor in Cox regression analysis (28). Miller and Nicholsen reported on 52 cases of reticulum cell sarcoma of bone and found tumor regression with prolonged survival associated either with infection or with treatment by bacterial toxin therapy (29). Older studies similarly found association between infection and improved survival in melanoma (30) and acute lymphoblastic leukemia (31). Finally, a canine study of limb-salvage surgery for osteosarcoma similarly reported survival advantage of post-operative infection (32).

\section{METHODOLOGICAL CONSTRAINTS IN AVAILABLE CLINICAL LITERATURE}

Several methodological issues likely explain conflicting results from the clinical studies described above. First, a retrospective study design does not allow for the control of many variables such as inconsistent treatment of post-operative bacterial infection.
Although discussed as confounders, the near-universal use of peri-operative steroids and adjuvant chemo-radiation should ideally not be seen as confounder in the modern era. Nonetheless, it is imperative to mention here the steroid-induced systemic immunosuppression and neutrophil demargination as well as direct radiation-induced toxicity to tumor resident immune cells. These effects of peri-operative steroids and adjuvant chemo-radiation can be expected to confound the survival benefit of infection on survival in GBM patients. Also, in patients treated for recurrent GBM, i.e., those who have failed standard of care adjuvant treatment, the use of many second-line agents, including immune-modulators [such as bevacizumab, a monoclonal antibody that binds to vascular endothelial growth factor (VEGF) and inhibits the growth of tumor blood vessel] are likely to act as potential confounders. Another variable is the severity of infection, i.e., superficial vs. deep. De Bonis et al. (20) reported a significant survival benefit of deep post-operative infections. A similar trend was reported by Bohman et al. (19). One could argue that involvement of resection cavity would provide the best probability for tumor antigen presentation to host lymphocytes and the highest likelihood of a targeted antitumoral immune response (19).

A major issue with clinical studies evaluating possible survival benefit of post-operative bacterial infections is the rarity of postoperative infections (given the sterile techniques used and the widespread antibiotics prophylaxis in present day neurosurgical 
practice) produces a small case group, which reduces the power of any study. For instance, the study by De Bonis et al. (20) identified 197 patients with primary GBM during a 7-year retrospective study period, and only 10 out of 197 (5.08\%) patients had post-operative bacterial infections. Similarly, the study by Chen and colleagues evaluating a national database of 3,784 GBM patients reported that $154(4.2 \%)$ patients had post-operative infection (21).

The most common organisms in the studies by Salle et al. (22), De Bonis et al. (20) and Bohman et al. (19) were gram positive bacteria (Staphylococcus aureus and Staphylococcus epidermidis in the first two studies, and Staphylococcus epidermidis and Propionibacterium acnes in the third one). Salle et al. (22) reported a significantly shorter survival time in patients with postoperative bacterial infections as compared to controls, De Bonis et al. (20) reported survival benefit and Bohman et al. (19) didn't find any survival advantage with infection. Another smaller case series reported a survival benefit in GBM patients with gram positive bacterial infections (23). While the largest clinical study on topic didn't report the type of infections involved (21), another series reported survival benefit after infection with a Gram negative organism, Enterobacter (Klebsiella) aerogenes (24). While Coley's studies focused primarily on survival benefit of Gram positive (erysipelas) toxins, the beneficial effect of therapeutic strategies utilizing regimens based on Gram negative bacteria-associated lipopolysaccharide both in in vitro and in vivo animal model studies against glioma cells $(33,34)$ support the notion of survival benefit induced by Gram negative infections also.

\section{MECHANISM(S) IMPLICATED IN SURVIVAL BENEFIT OF BACTERIAL INFECTIONS IN GBM}

Several theories have been proposed to explain how bacterial infection could lead to improved survival in GBM patients. De Bonis et al. (20) hypothesized that proliferation of bacteria is likely to induce local competition for resources between the tumor cells and the replicating microorganisms. Bacteria such as Staphylococcus aureus employ immune-evasion techniques such as sequestration of protein products and nutrients such as iron that are vital to sustain the vasculature and immense metabolic demands of neoplastic cells. Bohman et al. (19) suggested that infection within or near the tumor bed may stimulate the patient's immune response, thus resulting in an endogenous immune targeting against glioma cells. A biological argument that encompasses the ability of bacterial infections to induce augmented immunostimulatory response and evoke a cascade of cytokines and chemokines, some of which also exert anticancer effects, has been put forth (20). Modern biotechnology is harnessing this therapeutic potential by employing genetically modified bacteria to fight cancer (18, 35). Figure 1 provides a schematic of potential mechanisms of beneficial effect of post-operative bacterial infections on survival in GBM patients. The intrinsic CNS immune milieu [comprising of macrophages $(36,37)$ and glymphatic system (network of vessels that clear waste from the CNS) (38)] is subverted by growing GBM, and in this regards, the endogenous immune targeting against GBM cells by bacterial infections can exert a beneficial effect.

As mentioned above, local release of cytokines and activation of cancer-targeting immune cells could be the main mechanism by which bacterial infection may increase survival in GBM. The intracavitary introduction of interleukin-2 (a cytokine predominantly secreted by activated $\mathrm{T}$ - cells and a key player in the cell-mediated immune response) and lymphokineactivated killer cells was reported to improve survival in patients with recurrent malignant glioma (39). Interleukin2 gene therapy was also found to be beneficial in a GBM patient (40). Similarly, tumor necrosis factor alpha (TNF $\alpha$, an inflammatory cytokine produced by macrophages/monocytes during acute inflammation that is responsible for a diverse range of signaling events within cells, leading to necrosis or apoptosis), was found to reduce GBM growth both in vitro and in vivo $(41,42)$. Cytokine-targeted immunotherapy has been identified as a potential therapeutic strategy for gliomas and is an active area of research in the neuro-oncology field (43-45). For example, reducing expression of tumor cell-secreted cytokine inhibitors induced apoptosis of glioma cells (44). A number of bacteria associated antigens could act as immunostimulatory agents against proliferating glioma cells $(23,24)$.

The hypothesis of bacterial toxins-mediated immunotherapy for GBM is indirectly supported by observations in animal models and humans. For instance, a study reported that intracerebrally implanted heat-inactivated staphylococcal epitopes mixed with 9L gliosarcoma cells in Wistar rats, led to significantly prolonged survival than experimental controls (46). In a study by Tanaka and colleagues, Picibanil, also called OK-432 (an immunopotentiator and a low virulent mutant strain of Lancefield's Type III, Group A Streptococcus pyogenes) was injected intratumorally in 13 patients with malignant brain tumors, resulting in significant tumor regression in $50 \%$ of patients (47). Further indirect evidence comes from basic science studies of antitumor effects of bacterial toxins. An investigation by Duong and colleagues found that toxins from bacteria can directly induce apoptosis in tumor cells and increase neutrophil recruitment to the tumor microenvironment (TME) $(35,48)$. Bacterial toxins can also upregulate connexin 43 (a ubiquitous protein that forms gap junctions and that is normally lost during tumor progression), which in turns creates bacterial-induced gap junctions between tumor cells and dendritic cells and allows for cross-presentation of tumor antigens to the dendritic cells (49). This ultimately activates cytotoxic $\mathrm{T}$ cells against the tumor to limit its growth (49). Similarly, bacterial flagellin can also increase the antitumor response of $\mathrm{CD}^{+}$-cells (50).

The immunologic evasion of GBM is well documented; several blocking factors are produced by this type of brain tumor which suppress cytotoxic lymphocytes $(3,51)$. Higher expression of Immune Checkpoint (IC) molecules such as PD-L1 which provide inhibitory signals to $\mathrm{T}$ cells has been documented $(52,53)$, and IC Inhibitors (ICI) are presently being evaluated 


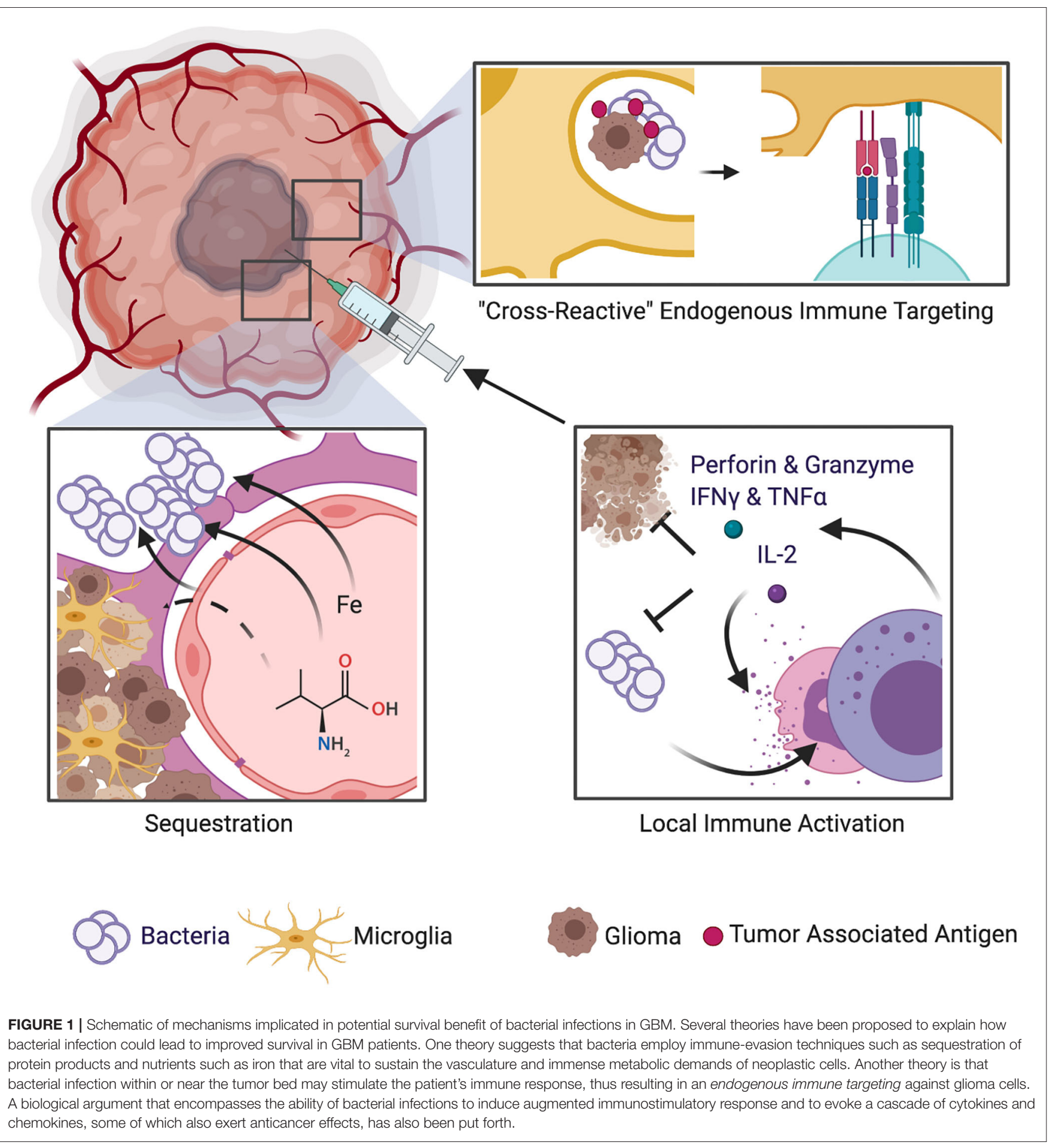

as potential GBM treatment in clinical trials (54). These data support the concept of immune evasion by GBM. It seems likely from preclinical and clinical data bacterial infections elicit some immunological cross-reactive attack that is directed not only against the infectious agent but also against the tumor cells. This augmented, "cross-reactive" immunostimulatory response to subvert infection, also has antitumor effect.

\section{CONCLUSION}

Historical evidence suggests beneficial effect of bacterial infections in tumor regression in general. There are plausible explanations from immunobiology for the mechanism of this potential anti-tumor activity in GBM patients. However, the available clinical neurosurgical literature fails to confirm such 
an association and a prospective randomized study on the topic is clearly not possible. While available clinical studies do not provide definitive association between post-operative bacterial infection and prolonged survival, immunobiology literature strongly suggests exploring genetically modified pathogens in a multimodality treatment approach for GBM.

\section{REFERENCES}

1. Siegel R, Naishadham D, Jemal A. Cancer statistics, 2013. CA Cancer J Clin. (2013) 63:11-30. doi: 10.3322/caac.21166

2. Chen R, Cohen AL, Colman H. Targeted therapeutics in patients with highGrade gliomas: past, present, and future. Curr. Treat Options Oncol. (2016) 17:42. doi: 10.1007/s11864-016-0418-0

3. Magana-Maldonado R, Chavez-Cortez EG, Olascoaga-Arellano NK, Lopez-Mejia M, Maldonado-Leal FM, Sotelo J, et al. Immunological evasion in glioblastoma. Biomed Res Int. (2016) 2016:7487313. doi: 10.1155/2016/7487313

4. Young RM, Jamshidi A, Davis G, Sherman JH. Current trends in the surgical management and treatment of adult glioblastoma. Ann Transl Med. (2015) 3:121. doi: 10.3978/j.issn.2305-5839.2015.05.10

5. Jain KK. A critical overview of targeted therapies for glioblastoma. Front Oncol. (2018) 8:419. doi: 10.3389/fonc.2018.00419

6. Lukas RV, Wainwright DA, Ladomersky E, Sachdev S, Sonabend AM, Stupp R. Newly diagnosed glioblastoma: a Review on clinical management. Oncology (Williston Park). (2019) 33:91-100.

7. Stupp R, Mason WP, Van Den Bent MJ, Weller M, Fisher B, Taphoorn MJ, et al. Radiotherapy plus concomitant and adjuvant temozolomide for glioblastoma. N Engl J Med. (2005) 352:987-96. doi: 10.1056/NEJMoa043330

8. Nuno M, Birch K, Mukherjee D, Sarmiento JM, Black KL, Patil CG. Survival and prognostic factors of anaplastic gliomas. Neurosurgery. (2013) 73:458-65; quiz 465. doi: 10.1227/01.neu.0000431477.02408.5e

9. Hegi ME, Diserens AC, Gorlia T, Hamou MF, De Tribolet N, Weller M, et al. MGMT gene silencing and benefit from temozolomide in glioblastoma. NEngl J Med. (2005) 352:997-1003. doi: 10.1056/NEJMoa043331

10. Stupp R, Hegi ME, Mason WP, Van Den Bent MJ, Taphoorn MJ, Janzer RC, et al. Effects of radiotherapy with concomitant and adjuvant temozolomide versus radiotherapy alone on survival in glioblastoma in a randomised phase iII study: 5-year analysis of the eORTC-NCIC trial. Lancet Oncol. (2009) 10:459-66. doi: 10.1016/S1470-2045(09)70025-7

11. Weller M, Stupp R, Reifenberger G, Brandes AA, Van Den Bent MJ, Wick W, et al. MGMT promoter methylation in malignant gliomas: ready for personalized medicine? Nat Rev Neurol. (2010) 6:39-51. doi: 10.1038/nrneurol.2009.197

12. Nauts HC. Bacteria and cancer-antagonisms and benefits. Cancer Surv. (1989) 8:713-23.

13. Nauts HC, Fowler GA, Bogatko FH. A review of the influence of bacterial infection and of bacterial products (Coley's toxins) on malignant tumors in man; a critical analysis of 30 inoperable cases treated by coley's mixed toxins, in which diagnosis was confirmed by microscopic examination selected for special study. Acta Med Scand Suppl. (1953) 276:1-03.

14. Coley WB. The treatment of malignant tumors by repeated inoculations of erysipelas. With a report of ten original cases. 1893. Clin Orthop Relat Res. (1991) 3:3-11.

15. Mccarthy EF. The toxins of william coley b, and the treatment of bone and soft-tissue sarcomas. Iowa Orthop J. (2006) 26:154-8.

16. Hoption Cann SA, Van Netten JP, Van Netten C. Dr william coley and tumour regression: a place in history or in the future. Postgrad Med J. (2003) 79:672-80.

17. Miller JT, Rahimi SY, Lee M. History of infection control and its contributions to the development and success of brain tumor operations. Neurosurg Focus. (2005) 18:e4. doi: 10.3171/foc.2005.18.4.5

18. Zhou S, Gravekamp C, Bermudes D, Liu K. Tumour-targeting bacteria engineered to fight cancer. Nat Rev Cancer. (2018) 18:727-743. doi: 10.1038/s41568-018-0070-z

\section{AUTHOR CONTRIBUTIONS}

SK, EM, TH, BS, CB, and MC, wrote the initial draft and edited the final version of the manuscript. $\mathrm{MC}$ and $\mathrm{CB}$ provided overall supervision for the manuscript. All authors contributed to the article and approved the submitted version.

19. Bohman LE, Gallardo J, Hankinson TC, Waziri AE, Mandigo CE, Mckhann, et al. The survival impact of postoperative infection in patients with glioblastoma multiforme. Neurosurgery. (2009) 64:828-34; discussion 834825. doi: 10.1227/01.NEU.0000343525.89321.C5

20. De Bonis P, Albanese A, Lofrese G, De Waure C, Mangiola A, Pettorini $\mathrm{BL}$, et al. Postoperative infection may influence survival in patients with glioblastoma: simply a myth? Neurosurgery. (2011) 69:864-8; discussion 868869. doi: 10.1227/NEU.0b013e318222adfa

21. Chen YR, Ugiliweneza B, Burton E, Woo SY, Boakye M, Skirboll S. The effect of postoperative infection on survival in patients with glioblastoma. $J$ Neurosurg. (2017) 127:807-11. doi: 10.3171/2016.8.JNS16836

22. Salle H, Deluche E, Couve-Deacon E, Beaujeux AC, Pallud J, Roux A, et al. Surgical site infections after glioblastoma surgery: results of a multicentric retrospective study. Infection. (2020). doi: 10.1007/s15010-020-01534-0. [Epub ahead of print].

23. Alexiou GA, Kallinteri A, Michos E, Zagorianakou P, Priavali E, Pachatouridis $\mathrm{D}$, et al. The influence of postoperative infection in survival of patients with high-grade gliomas. Neuroimmunol Neuroinflamm. (2015) 2:1820. doi: 10.4103/2347-8659.149418

24. Bowles AP Jr, Perkins E. Long-term remission of malignant brain tumors after intracranial infection: a report of four cases. Neurosurgery. (1999) 44:636-42; discussion 642-633. doi: 10.1097/00006123-199903000-00110

25. Walker DG, Pamphlett R. Prolonged survival and pulmonary metastasis after local cure of glioblastoma multiforme. J Clin Neurosci. (1999) 6:678. doi: 10.1016/S0967-5868(99)90611-2

26. Kapp JP. Microorganisms as antineoplastic agents in cNS tumors. Arch Neurol. (1983) 40:637-42. doi: 10.1001/archneur.1983.04050090073012

27. Ruckdeschel JC, Codish SD, Stranahan A, Mckneally MF. Postoperative empyema improves survival in lung cancer. Documentation and analysis of a natural experiment. $N$ Engl J Med. (1972) 287:1013-7. doi: 10.1056/NEJM197211162872004

28. Jeys LM, Grimer RJ, Carter SR, Tillman RM, Abudu A. Post operative infection and increased survival in osteosarcoma patients: are they associated? Ann Surg Oncol. (2007) 14:2887-95. doi: 10.1245/s10434-007-9483-8

29. Miller TR, Nicholson JT. End results in reticulum cell sarcoma of bone treated by bacterial toxin therapy alone or combined with surgery and-or radiotherapy (47 cases) or with concurrent infection (5 cases). Cancer. (1971) 27:524-48. doi: 10.1002/1097-0142(197103)27:3<524::AIDCNCR2820270305>3.0.CO;2-Z

30. Papachristou DN, Fortner JG. Effect of postoperative wound infection on the course of stage iI melanoma. Cancer. (1979) 43:1106-11. doi: 10.1002/10970142(197903)43:3<1106::AID-CNCR2820430349>3.0.CO;2-M

31. Bierman HR, Crile DM, Dod KS, Kelly KH, Petrakis NL, White LP, et al. Remissions in leukemia of childhood following acute infectious disease: staphylococcus and streptococcus, varicella, feline panleukopenia. Cancer. (1953) 6:591-605. doi: 10.1002/1097-0142(195305)6:3<591::AIDCNCR2820060317>3.0.CO;2-M

32. Lascelles BD, Dernell WS, Correa MT, Lafferty M, Devitt CM, Kuntz CA, et al. Improved survival associated with postoperative wound infection in dogs treated with limb-salvage surgery for osteosarcoma. Ann Surg Oncol. (2005) 12:1073-83. doi: 10.1245/ASO.2005. 01.011

33. Chicoine MR, Won EK, Zahner MC. Intratumoral injection of lipopolysaccharide causes regression of subcutaneously implanted mouse glioblastoma multiforme. Neurosurgery. (2001) 48:607-14; discussion 614-605. doi: 10.1097/00006123-200103000-00032

34. Won EK, Zahner MC, Grant EA, Gore P, Chicoine MR. Analysis of the antitumoral mechanisms of lipopolysaccharide 
against glioblastoma multiforme. Anticancer Drugs. (2003) 14:457-66. doi: 10.1097/00001813-200307000-00012

35. Agrawal N, Bettegowda C, Cheong I, Geschwind JF, Drake CG, Hipkiss EL, et al. Bacteriolytic therapy can generate a potent immune response against experimental tumors. Proc Natl Acad Sci USA. (2004) 101:151727. doi: 10.1073/pnas.0406242101

36. Nimmerjahn A, Kirchhoff F, Helmchen F. Resting microglial cells are highly dynamic surveillants of brain parenchyma in vivo. Science. (2005) 308:13148. doi: $10.1126 /$ science. 1110647

37. Deczkowska A, Amit I, Schwartz M. Microglial immune checkpoint mechanisms. Nat Neurosci. (2018) 21:77986. doi: 10.1038/s41593-018-0145-x

38. Jessen NA, Munk AS, Lundgaard I, Nedergaard M. The glymphatic system: a Beginner's guide. Neurochem Res. (2015) 40:2583-99. doi: 10.1007/s11064-015-1581-6

39. Hayes RL, Koslow M, Hiesiger EM, Hymes KB, Hochster HS, Moore EJ, et al. Improved long term survival after intracavitary interleukin-2 and lymphokine-activated killer cells for adults with recurrent malignant glioma. Cancer. (1995) 76:840-52. doi: 10.1002/1097-0142(19950901)76:5<840::AIDCNCR2820760519>3.0.CO;2-R

40. Sobol RE, Fakhrai H, Shawler D, Gjerset R, Dorigo O, Carson C, et al. Interleukin-2 gene therapy in a patient with glioblastoma. Gene Ther. (1995) 2:164-7.

41. Kondo S, Yin D, Takeuchi J, Morimura T, Miyatake SI, Nakatsu S, et al. Tumour necrosis factor-alpha induces an increase in susceptibility of human glioblastoma u87-MG cells to natural killer cell-mediated lysis. Br J Cancer. (1994) 69:627-32. doi: 10.1038/bjc.1994.123

42. Villeneuve J, Tremblay $P$, Vallieres L. Tumor necrosis factor reduces brain tumor growth by enhancing macrophage recruitment and microcyst formation. Cancer Res. (2005) 65:3928-36. doi: 10.1158/0008-5472.CAN-04-3612

43. Thomas AA, Ernstoff MS, Fadul CE. Immunotherapy for the treatment of glioblastoma. Cancer J. (2012) 18:59-68. doi: 10.1097/PPO.0b013e3182431a73

44. Yeung YT, Mcdonald KL, Grewal T, Munoz L. Interleukins in glioblastoma pathophysiology: implications for therapy. Br J Pharmacol. (2013) 168:591606. doi: 10.1111/bph.12008

45. Lamano JB, Ampie L, Choy W, Kesavabhotla K, Didomenico JD, Oyon DE, et al. Immunomonitoring in glioma immunotherapy: current status and future perspectives. J Neurooncol. (2016) 127:1-3. doi: 10.1007/s11060-015-2018-4

46. Lohr M, Molcanyi M, Poggenborg J, Spuentrup E, Runge M, Rohn G, et al. Intracerebral administration of heat-inactivated staphylococcus epidermidis enhances oncolysis and prolongs survival in a 9L orthotopic gliosarcoma model. Cell Physiol Biochem. (2013) 31:614-24. doi: 10.1159/000350081

47. Tanaka R, Sekiguchi K, Suzuki Y, Sobue H, Ueki K. Preliminary evaluation of intratumoral injection of a streptococcus pyrogenes preparation in patients with malignant brain tumors. Cancer. (1980) 46:1688-94. doi: 10.1002/10970142(19801001)46:7<1688::AID-CNCR2820460731>3.0.CO;2-L

48. Duong MT, Qin Y, You SH, Min JJ. Bacteria-cancer interactions: bacteria-based cancer therapy. Exp Mol Med. (2019) 51:115. doi: 10.1038/s12276-019-0297-0

49. Saccheri F, Pozzi C, Avogadri F, Barozzi S, Faretta M, Fusi P, et al. Bacteria-induced gap junctions in tumors favor antigen crosspresentation and antitumor immunity. Sci Transl Med. (2010) 2:44ra57. doi: 10.1126/scitranslmed.3000739

50. Sfondrini L, Rossini A, Besusso D, Merlo A, Tagliabue E, Menard S, et al. Antitumor activity of the tLR-5 ligand flagellin in mouse models of cancer. J Immunol. (2006) 176:6624-30. doi: 10.4049/jimmunol.176. 11.6624

51. Sampson JH, Gunn MD, Fecci PE, Ashley DM. Brain immunology and immunotherapy in brain tumours. Nat Rev Cancer. (2020) 20:1225. doi: 10.1038/s41568-019-0224-7

52. Garber ST, Hashimoto Y, Weathers SP, Xiu J, Gatalica Z, Verhaak RG, et al. Immune checkpoint blockade as a potential therapeutic target: surveying cNS malignancies. Neuro Oncol. (2016) 18:1357-66. doi: 10.1093/neuonc/ now132

53. Chen RQ, Liu F, Qiu XY, Chen XQ. The prognostic and therapeutic value of $\mathrm{pD}-\mathrm{L1}$ in glioma. Front Pharmacol. (2018) 9:1503. doi: 10.3389/fphar.2018.01503

54. Romani M, Pistillo MP, Carosio R, Morabito A, Banelli B. Immune checkpoints and innovative therapies in glioblastoma. Front Oncol. (2018) 8:464. doi: $10.3389 /$ fonc. 2018.00464

Conflict of Interest: The authors declare that the research was conducted in the absence of any commercial or financial relationships that could be construed as a potential conflict of interest.

Copyright $@ 2021$ Kazim, Martinez, Hough, Spangler, Bowers and Chohan. This is an open-access article distributed under the terms of the Creative Commons Attribution License (CC BY). The use, distribution or reproduction in other forums is permitted, provided the original author(s) and the copyright owner(s) are credited and that the original publication in this journal is cited, in accordance with accepted academic practice. No use, distribution or reproduction is permitted which does not comply with these terms. 